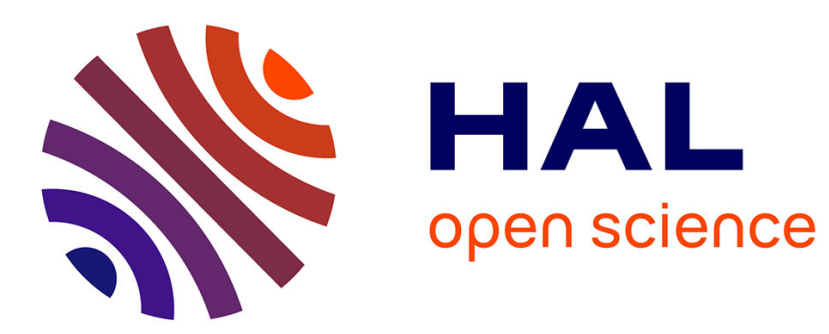

\title{
Chromatin immunoprecipitation in microfluidic droplets: towards fast and cheap analyses
}

Bruno Teste, Jerome Champ, Arturo Londono-Vallejo, Stéphanie Descroix, Laurent Malaquin, Jean-Louis Viovy, Irena Draskovic, Guillaume Mottet

\section{- To cite this version:}

Bruno Teste, Jerome Champ, Arturo Londono-Vallejo, Stéphanie Descroix, Laurent Malaquin, et al.. Chromatin immunoprecipitation in microfluidic droplets: towards fast and cheap analyses. Lab on a Chip, 2017, 17 (3), pp.530 - 537. 10.1039/C6LC01535B . hal-01503119

\section{HAL Id: hal-01503119 https://hal.sorbonne-universite.fr/hal-01503119}

Submitted on 6 Apr 2017

HAL is a multi-disciplinary open access archive for the deposit and dissemination of scientific research documents, whether they are published or not. The documents may come from teaching and research institutions in France or abroad, or from public or private research centers.
L'archive ouverte pluridisciplinaire HAL, est destinée au dépôt et à la diffusion de documents scientifiques de niveau recherche, publiés ou non, émanant des établissements d'enseignement et de recherche français ou étrangers, des laboratoires publics ou privés. 


\title{
Lab on a Chip
}

\section{Chromatin immunoprecipitation in microfluidic droplets: towards fast and cheap analyses}

\begin{abstract}
Bruno Teste, ${ }^{a}$ Jerome Champ, ${ }^{a}$ Arturo Londono-Vallejo, ${ }^{\text {b,c }}$ Stéphanie Descroix, ${ }^{a}$ Laurent Malaquin, ${ }^{a, d}$ Jean-Louis Viovy, ${ }^{a}$ Irena Draskovic ${ }^{b, c}$ and Guillaume Mottet ${ }^{a, e}$

Genetic organization is governed by the interaction of DNA with histone proteins, and differential modifications of these proteins is a fundamental mechanism of gene regulation. Histone modifications are primarily studied through chromatin immunoprecipitation (ChIP) assays, however conventional ChIP procedures are time consuming, laborious and require a large number of cells. Here we report for the first time the development of ChIP in droplets based on a microfluidic platform combining nanoliter droplets, magnetic beads (MB) and magnetic tweezers (MT). The droplet approach enabled compartmentalization and improved mixing, while reducing the consumption of samples and reagents in an integrated workflow. Anti-histone antibodies grafted to MB were used as a solid support to capture and transfer the target chromatin from droplets to droplets in order to perform chromatin immunoprecipitation, washing, elution and purification of DNA. We designed a new ChIP protocol to investigate four different types of modified histones with known roles in gene activation or repression. We evaluated the performances of this new ChIP in droplet assay in comparison with conventional methods. The proposed technology dramatically reduces analytical time from a few days to 7 hours, simplifies the ChIP protocol and decreases the number of cells required by 100 fold while maintaining a high degree of sensitivity and specificity. Therefore this droplet-based ChIP assay represents a new, highly advantageous and convenient approach to epigenetic analyses.
\end{abstract}

\section{Introduction}

Chromatin is composed of DNA, RNA and accessory proteins such as histones ${ }^{1,2}$. Chromatin remodelling occurs through epigenetic processes and influences gene regulation. Some epigenetic changes have been strongly associated with human pathologies, including cancer ${ }^{3}$ and Huntington's disease ${ }^{4}$, by promoting aberrant gene expression. Altered epigenetic processes may therefore serve as potential biomarkers in medical diagnostics; and furthermore offer new therapeutic targets. These processes are mainly based on DNA methylation and modifications to histone proteins ${ }^{5,6}$ including acetylation, methylation, phosphorylation, ubiquitination, sumoylation, deimination, isomerization and poly-ADP-ribosylation. Such modifications will affect protein/DNA interactions, thereby influencing the accessibility of the locus to transcription machinery. Yet how these processes occur to regulate gene expression in the cell is not fully understood.

Chromatin immunoprecipitation (ChIP) assays are conventional and widely used techniques to investigate protein-DNA interactions at specific locations in the genome ${ }^{7}$. Briefly, the standard ChIP protocol consists of fixation and lysis of the cells of interest before chromatin fragmentation. Then beads grafted with anti-histone antibodies or other direct DNA-binders are used to specifically extract the target chromatin. Finally, the DNA is released, purified and analysed by quantitative-PCR, hybridization or next generation sequencing. Increased accessibility of the latter contributes in a large part to the renewed interest in developing more efficient ChIP assays ${ }^{8}$. Conventional ChIP assays suffer from three main drawbacks. First, the procedure

\footnotetext{
a.Institut Curie, PSL Research University, CNRS UMR 168, Institut Pierre-Gilles de Gennes, MMBM group, 6 Rue Calvin 75005 Paris, France

Tel: +33 (0)1 443891 83; E-mail: guillaume.mottet@pasteur.fr

b. Institut Curie, PSL Research University, CNRS, UMR 3244, Telomeres and Cancer Laboratory, F-75248, Paris, France

c. Sorbonne Universités, UPMC Univ Paris 06, CNRS, UMR3244, 75005, Paris, France

d. Current affiliation: CNRS, LAAS, 7 avenue du colonel Roche, F-31400 Toulouse,

France

e. Current affiliation : Institut Pasteur, INSERM unit 1222, ATP, 25 rue du docteur

Roux, 75015, Paris, France

Electronic Supplementary Information (ESI) available: See OI: 10.1039/x0xx00000x
} 
requires a large number of cells $\left(10^{6}-10^{7}\right.$ cells) due to cell loss and inefficiency of chromatin extraction, which is a considerable limitation for studying rare cell populations as in stem cell differentiation, embryo development or oncogenesis. Secondly, the ChIP protocol is both time consuming and technically challenging, and the entire procedure can last from 2 to 7 days. Finally, standard ChIP assays offer only low throughput analyses. There has been substantial efforts in the recent years to improve ChIP performances by reducing the requisite number of cells ${ }^{9-11}$, by shortening the procedure ${ }^{12}$ and by increasing assay throughput ${ }^{13}$. Nevertheless, it is not yet possible to simultaneously overcome these limitations to obtain a ChIP procedure that may be performed rapidly, easily and on small numbers of cells.

Microfluidics-based technologies appeared as a powerful tool to overcome ChIP limitations since they reduce sample consumption and allow the integration, automation and high throughput of multi-step analytical procedures. Microfluidics has been largely developed for proteins ${ }^{14}$, DNA, RNA and cells analyses ${ }^{15}$ but very few studies report on ChIP integration at a microfluidic scale. Wu et al. developed an automated microfluidic-based platform to perform 16 assays simultaneously using only 10000 cells for each experiment, by achieving increased chromatin yield during the immunoprecipitation steps. This integrated approach offers greater sensitivity than conventional procedures ${ }^{16}$. Geng et al. developed an assay that permits the analysis of histone modifications from as few as 50 cells by using magnetic beads in a microfluidic chamber ${ }^{17}$. More recently, Cao et al. combined packed beads and oscillatory washing to effectively remove nonspecific adsorption and obtain high yields of highly enriched DNA ${ }^{18}$. The same team proposed also another chip based on a microchamber integrating an ultrasonic transducer. The internal sonication enables both shearing of chromatin/DNA and mixing/washing of immunoprecipitation beads. This chip allowed sensitive tests starting with 100 cross-linked cells ${ }^{19}$. Although such microfluidic strategies have improved chromatin extraction efficiency from small numbers of cells, the integrated procedure on a chip has been limited to cell lysis and chromatin extraction, and does not include the subsequent steps: reverse cross-linking of DNA from proteins and DNA purification. These latter two steps are particularly time consuming and require organic solvents (chloroform, phenol, alcohol).

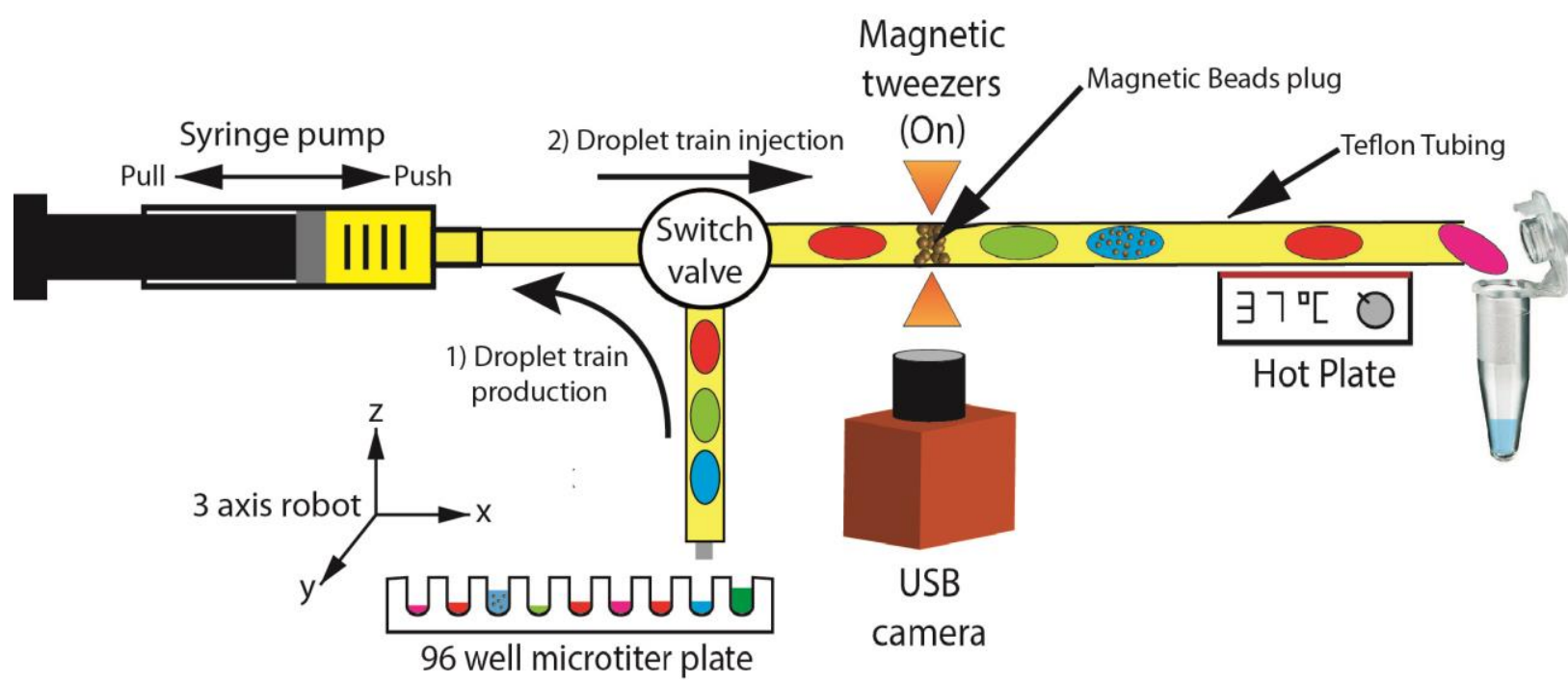

Fig.1. Schematic of the experimental set-up. Teflon tubing was used to generate trains of droplets by sequentially aspirating aqueous (reagents and samples) and oil solutions from a microtiter plate using a syringe pump combined with a pipetting robot. The train of droplets was generated in reverse order based on the syringe pump aspirating mode and then pushed through the tubing toward the magnetic tweezers in order to perform the subsequent steps of the analytical procedure. Activation and deactivation of magnetic tweezers allowed extraction and redispersion of magnetic beads within the droplets. Handling of droplets within the tube was achieved by back and forth movements generated by switching from injection to aspiration mode on the syringe pump.

In this context, we developed an integrated ChIP procedure, from chromatin immunoprecipitation to DNA purification, using a lab on tube platform that has been previously described (see Fig.1, Supplementary Fig.2) ${ }^{20-23}$. This platform comprises a single $300 \mu \mathrm{m}$ diameter Teflon tubing and a syringe pump that enables the back and forth movement of droplets. Given that droplets are confined within the tube, internal flows occurring within each droplet improve the internal mixing of reagents. This platform also takes advantage of magnetic beads $(\mathrm{MB})$ and a single pair of magnetic tweezers (MT). MB within the droplets are used as a solid support to transfer the target DNA from droplet to droplet thanks to the activation/deactivation of MT. As such, this platform accomplishes the sequential steps of chromatin extraction, reverse cross-linking and DNA purification. As described above, previously developed microfluidic systems improve cell lysis and chromatin extraction efficiency. While allowing the manipulation of a small number of cells, these approaches remain expensive, complex and limited to the first step of the ChIP procedure. The platform we describe herein offers an automated, cheap and simple analytical procedure, despite not yet 
achieving the high performance of other assays in terms of cell numbers. Moreover, the compartmentalization within nanoliter droplets (i) prevents cross contamination, (ii) quickens reaction kinetics due to internal recirculation flows, (iii) reduces samples and reagents consumption and (iv) simplifies the procedure compared to a conventional ChIP protocol that requires skilled operators. Finally, the combination of tubing, droplets and MB offers multiple trapping-release sequences, which is of great importance in multi-step analytical procedures. In this way, the droplet platform we propose successfully integrates the whole procedure from chromatin extraction to DNA purification, whereas conventional monophasic microfluidic is limited to few steps of the whole analytical procedure.

In this work we investigated the influence of $\mathrm{MB}$, antibodies and initial chromatin quantities on ChIP assay performances. Then we used this novel droplet ChIP assay to analyse histone modifications at the mir-200b gene region from human fibrosarcoma HT1080 cells. Finally, we compared the analytical performances and the results concerning histone modifications from ChIP in droplets with the performances of a conventional ChIP approach.

\section{Materials and methods}

\section{A Cell culture and Chromatin preparation}

HT1080, a human fibrosarcoma cell line, was cultured in DMEM GlutaMAX medium (Gibco) supplemented with $10 \%$ fetal calf serum (Dako), 1\% non-essential amino acids and $1 \mathrm{mM}$ pyruvate (both Gibco). For chromatin preparation cells were seeded in $300 \mathrm{~cm}^{2}$ flasks at about $40 \%$ confluency $24 \mathrm{~h}$ prior to the experiment. For chromatin preparations, cells were fixed directly in culture dishes with $1 \%$ formaldehyde (Thermo Scientific) for $10 \mathrm{~min}$ at $37^{\circ} \mathrm{C}$. For reproducible fixation, a freshly prepared crosslinking solution containing $10 \%$ formaldehyde, $50 \mathrm{mM}$ Tris $\mathrm{pH} 8,100 \mathrm{mM} \mathrm{NaCl}, 1 \mathrm{mM}$ EDTA and $0.5 \mathrm{mM}$ EGTA was diluted 10 -fold in cell culture medium. Fixation was stopped by the addition of $1 / 20^{\text {th }}$ of the volume of $2.5 \mathrm{M}$ glycine and subsequent incubation at room temperature for $5 \mathrm{~min}$. Following three washes in ice-cold phosphate buffered saline (PBS) cells were recovered by scraping and washed once in cold PBS supplemented with protease inhibitors (Roche). Nuclei were prepared by homogenization in cold cell lysis buffer ( $5 \mathrm{mM}$ PIPES pH $8,85 \mathrm{mM} \mathrm{KCl}, 0.5 \% \mathrm{NP}-40$ ) and centrifugation at $1800 \mathrm{~g}$ for $10 \mathrm{~min}$ at $4^{\circ} \mathrm{C}$. Finally, nuclei prepared from two $300 \mathrm{~cm}^{2}$ flasks were lyzed in $1 \mathrm{ml}$ nuclei lysis buffer $(50 \mathrm{mM}$ Tris-HCl pH 8, $10 \mathrm{mM}$ EDTA pH $8,1 \%$ SDS) at room temperature and lysates were sonicated with Bioruptor Plus (Diagenode) for $30 \mathrm{cycles}$ of $30 \mathrm{sec}$ on, $30 \mathrm{sec}$ off, at $4^{\circ} \mathrm{C}$. Following a centrifugation at $12,000 \mathrm{~g}$ for $10 \mathrm{~min}$ at $4^{\circ} \mathrm{C}$, the cleared supernatants were snapfrozen in liquid nitrogen and stored at $-80^{\circ} \mathrm{C}$. The shearing efficiency was monitored by agarose gel electrophoresis after decrosslinking and purification of DNA. We routinely obtain chromatin preparations sheared to 250 to $500 \mathrm{bp}$.

\section{B Antibodies for ChIP}

The following antibodies were used (all rabbit): IgG (abcam, ab37415, lot GR135254, $5 \mathrm{mg} / \mathrm{ml}$ ), anti-H3 (abcam, ab1791, lot GR50122, $1 \mathrm{mg} / \mathrm{ml}$ ), anti-H3K4me3 (Active motif, 39159, lot 01609004, concentration unspecified), anti-H3K9ac (Millipore, 17658, lot 2035642, $1 \mathrm{mg} / \mathrm{ml}$ ), anti-H3K9me3 (abcam, ab8898, lot GF102533, $1 \mathrm{mg} / \mathrm{ml}$ ), anti-H3K27me3 (Ozyme, 9733S, lot 6, concentration unspecified).

\section{Conventional ChIP}

Preparation of blocked beads: Dynabeads Protein A (Invitrogen, 50\% slurry, $30 \mathrm{mg} / \mathrm{ml}$ beads) were washed three time with $1 \mathrm{X}$ ChIP dilution buffer (150 mM Tris-HCl pH 8, $15 \mathrm{mM} \mathrm{NaCl}, 1 \mathrm{mM}$ EDTA pH 8, 1\% Triton X-100, 0.01\% SDS) and blocked in 1X ChIP dilution buffer containing $1 \mathrm{mg} / \mathrm{ml}$ of BSA for 2 hours at $4^{\circ} \mathrm{C}$ on the rotating wheel. After three washes with $1 \mathrm{X}$ ChIP dilution buffer, beads were reconstituted back to $50 \%$ slurry using this buffer. For chromatin immunoprecipitations, $30 \mu \mathrm{g}$ of sonicated chromatin was diluted 10 fold in 1.1X ChIP dilution buffer and incubated for 2 hours with $20 \mu$ of blocked beads while rotating at $4^{\circ} \mathrm{C}$. After beads were discarded this pre-cleared chromatin was incubated overnight with an antibody of interest $(2.5 \mu \mathrm{g}$ or $10 \mu \mathrm{l}$ when concentration unspecified). Chromatin-antibody complexes were pulled down using $30 \mu \mathrm{L}$ of blocked beads ( 2 hours incubation at $4^{\circ} \mathrm{C}$ while rotating). The beads were washed for $10 \mathrm{~min}$ at $4^{\circ} \mathrm{C}$ in each of the following washing buffers: Low Salt Buffer (20 mM Tris-HCl pH 8, 150 mM NaCl, 2 mM EDTA pH 8, 1\% Triton X-100, 0.1\% SDS), High Salt Buffer (20 mM Tris-HCl pH 8, $500 \mathrm{mM} \mathrm{NaCl}, 2$ mM EDTA pH 8, 1\% Triton X-100, 0.1\% SDS), LiCl Buffer (10 mM Tris-HCl pH 8, 0.25 M LiCl, 1 mM EDTA pH 8, 1\% NP-40, 1\% Na Deoxycholate) and twice, $5 \mathrm{~min}$ each, in TE. ChIPed material was eluted by two 15 min incubations at room temperature with $225 \mu$ lelution buffer ( $0.1 \mathrm{M} \mathrm{NaHCO}$, 1\% SDS). Chromatin was reverse-crosslinked by adding $20 \mu \mathrm{l}$ of $5 \mathrm{M} \mathrm{NaCl}$ and incubated over night at $65^{\circ} \mathrm{C}$. DNA was submitted to RNase A digestion (at $0.4 \mathrm{mg} / \mathrm{ml}$ for 30 min at $37^{\circ} \mathrm{C}$ ) and proteinase $\mathrm{K}$ digestion (at $0.08 \mathrm{mg} / \mathrm{ml}$ for $1 \mathrm{~h}$ at $42^{\circ} \mathrm{C}$ ). DNA was extracted by UltraPure pheno:chloroform:isoamyl alcohol 25:24:1 (Thermo Fisher) and chloroform:isoamyl alcohol 24:1 (Sigma). DNA was precipitated with sodium acetate (1/10 v/v) and ethanol (2 v/v) over night at $-20^{\circ} \mathrm{C}$ prior to microcentrifugation for $30 \mathrm{~min}$ at $16,000 \mathrm{~g}$ at $4^{\circ} \mathrm{C}$. Precipitated DNA was washed with $70 \%$ ethanol and recentrifuged for 10 min under the same conditions. Dried DNA pellets were resuspended in $40 \mu$ l water.

\section{Droplet-based ChIP assay}




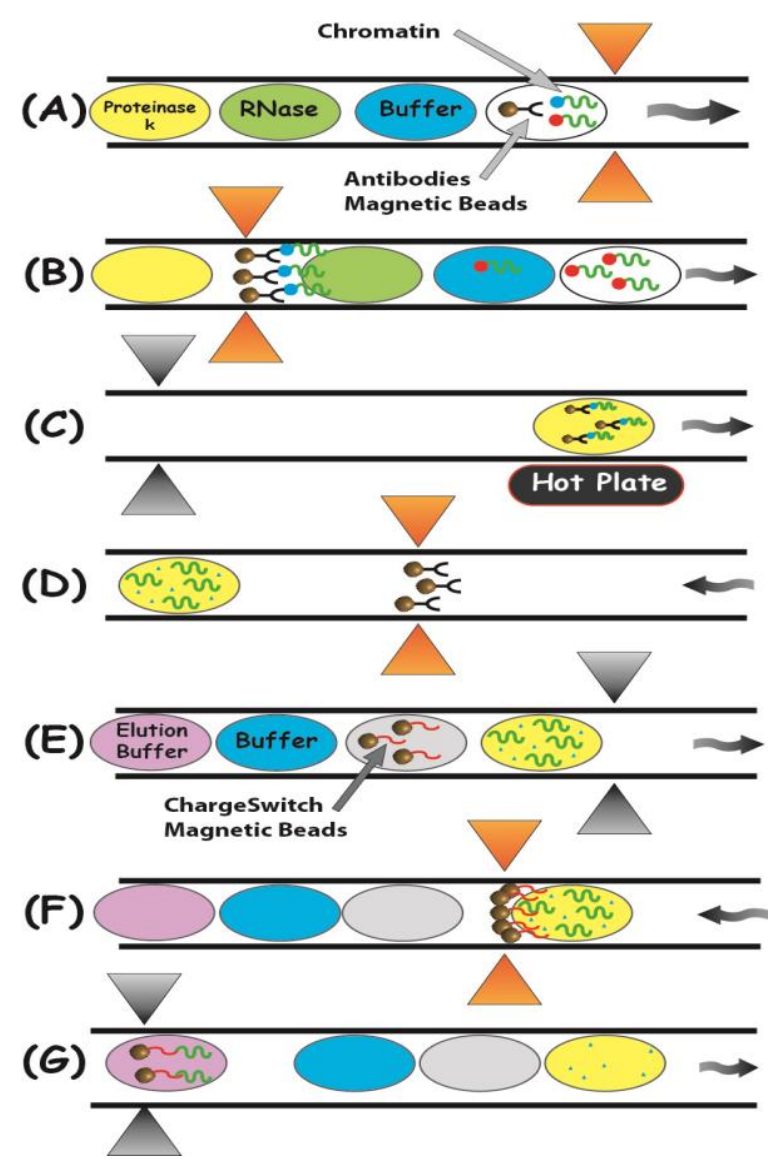

Fig.2. Principle of the droplets microfluidic ChIP platform. Droplets handling within the tube was based on forth and back movements generated by switching from pushing to aspirating mode on the syringe pump. A) Generation of the $1^{\text {st }}$ train of droplets made of: magnetic beads (MB) + antibodies + chromatin; washing buffer; RNase; Proteinase K. B) MB were confined between the magnetic tweezers (MT), extracted, rinsed in the washing buffer droplets, transferred in the RNase droplet for RNA digestion and extracted after 5 min incubation. C) $\mathrm{MB}$ were dispersed in proteinase $\mathrm{K}$ droplet for protein digestion and heated for $5 \mathrm{~min}$ at $70^{\circ} \mathrm{C}$ to release DNA from digested proteins. D) MB were discarded and E) a new train of droplets was generated: charge switch magnetic beads (CSMB), washing buffer and elution buffer droplets. F) CSMB were transferred to the droplet containing DNA and digested proteins (yellow droplet) to capture the DNA, G) before it was extracted, washed and eluted in elution buffer. CSMB were discarded before qPCR.

The analytical procedure within the droplets is depicted on Fig.2 (see supporting information for a more detailed procedure). Fluid and magnetic beads handling were performed using a previously described platform ${ }^{20,21}$. Briefly, Teflon tubing was inserted in between two magnetic tips made of Fe-Co soft magnetic alloys (AFK502, Imphy Alloys Arcelor Mittal). An electromagnetic coil (33.5 mm diameter, $6 \mathrm{~cm}$ long) made of 1000 loops of copper wire (0.8 $\mathrm{mm}$ diameter) was used to induce a magnetic excitation in one of the tips by applying current generated from adjustable power supply (0-4 A, 0-25 V). The second magnetic tip was placed in front of the first tip and was magnetized by influence. MB within the droplets were magnetically confined by switching on the current $(2 \mathrm{~A})$ and released in another droplet by switching off the current. After the release internal recirculation flows in the droplet induce shear forces that favor MB redispersion. Trains of aqueous droplets were generated by sequentially aspirating $100 \mathrm{~nL}$ of aqueous suspension (reagents and samples) and $200 \mathrm{~nL}$ of fluorinated oil (FC-40, 3M) mixed with $1 \mathrm{H}, 1 \mathrm{H}, 2 \mathrm{H}, 2 \mathrm{H}-$ perfluorodecan-1-ol, surfactant (Fluorochem) at $2 \%(w / w)$ in Teflon tubing (300 $\mu \mathrm{m}$ ID and $600 \mu \mathrm{m}$ OD, Sigma-Aldrich) used as microchannel. Fluid handling was performed using a syringe pump (Nemesys, Cetoni GmbH) with a 1-mL syringe (internal diameter of $0.4 \mathrm{~mm}$ ). The sequential generation of the droplets train was monitored using a three-axis robot to sample the different reagents and samples (RotAXYs, Cetoni $\mathrm{GmbH}$ ). Each reagent, sample and oil solutions, were previously stored in separate wells of a microtiter plate. The droplets were injected in the microfluidic device at $5 \mu \mathrm{L} / \mathrm{s}$ and were visualized using a portable USB camera (Dino-lite). A photo of the platform is provided in the supporting information (Supplementary Fig.2).

The procedure was performed in two steps since two different trains of droplets were generated. These trains were generated in reverse order and then pushed within the tube. The first one was generated in the following order: (1) one droplet of proteinase $\mathrm{K}(20 \mathrm{mg} / \mathrm{mL})$ diluted in citrate buffer at $\mathrm{pH} 6.5$; (2) one droplet of RNase $(10 \mathrm{mg} / \mathrm{mL})$; (3) five droplets of washing buffers (see section $\mathrm{C}$ and supporting information for more details); (4) one droplet containing a mix of anti-histone antibodies (from $10^{-2}$ to 4 $\mu \mathrm{g}$ ), magnetic beads (from 1 to $15 \mu \mathrm{g}$ ) and chromatin sample (from 0.1 to $12 \mu \mathrm{g}$ ), this mix was prepared and incubated for $4 \mathrm{~h}$ at 
$4^{\circ} \mathrm{C}$ before droplets generation. The process optimization was performed with anti- $\mathrm{H} 3$ antibodies while histones modification analyses were performed with anti-H3K4me3, anti-H3K9ac, anti-H3K9me3 and anti-H3K27me3 antibodies. Non-specific signal was evaluated using rabbit IgG antibody. All the incubation steps were performed with forth and back moving droplets at a flow rate of $5 \mu \mathrm{L} / \mathrm{s}$ (droplet velocity of $\sim 3 \times 10^{-3} \mathrm{~m} / \mathrm{s}$ ) thus allowing internal fluids recirculation and improving kinetics reactions. The first droplet containing the captured target chromatin on $\mathrm{MB}$ was confined between the magnetic tweezers and the five droplets of washing buffers passed through the MB cluster. The MB were then released in the RNAse droplet for 5 min. Finally, MB were extracted and transferred into the Proteinase $\mathrm{K}$ droplet for $5 \mathrm{~min}$ at $70^{\circ} \mathrm{C}$. This step allows the release of DNA from the proteins. After these incubations all the droplets except the proteinase $K$ droplet containing the DNA were discarded from the tube. A second train of droplets was generated in the tube containing the proteinase K droplet (with DNA). This $2^{\text {nd }}$ train of droplet was also generated in reverse order by using the ThermoFisher scientific ChargeSwitch ${ }^{\oplus}$ gDNA Tissue Kit. The train of droplets was made as follows: one droplet of elution buffer, three droplets of washing buffer and one droplet of charge switch magnetic beads (CSMB). The CSMB were transferred into the proteinase $\mathrm{K}$ droplet to capture the DNA for 10 min. Then the CSMB were extracted and washed with the droplet of washing buffer. Finally, the CSMB were released in the elution buffer and after 10 min of incubation, the CSMB were removed and the purified DNA droplet was collected in $5 \mu \mathrm{L}$ of water in a tube. The technique can be operated manually or automatically ${ }^{23}$.

\section{E Quantitative (q)-PCR assay}

Purified DNA recovered by ChIP was analyzed by real-time q-PCR. The DNA quantity was estimated from a qPCR standard curve generated from serial dilution of known DNA quantities. Samples were analyzed using the qPCR mix from GoTaq Promega Kit in the final volume of $25 \mu \mathrm{l}$ using up to $5 \mu \mathrm{L}$ of purified sample DNA, $12.5 \mu \mathrm{L}$ of GoTaq mix and $1 \mu \mathrm{L}$ of each primer, \#989 (ACGCAGAGGGAAGAACCTG) and \#990 (GACGGGCTTAATCAATGGTG), at $10 \mu \mathrm{M}$. These primers amplify 147 bp from the human miR-200b promoter region about $2.5 \mathrm{~kb}$ upstream of the transcription start site (Karina Jouravleva, personal communication). DNA was quantified using a smart cycler (Cepheid) using the following program: $3 \mathrm{~min}$ at $95^{\circ} \mathrm{C}(1 \mathrm{cycle})$ and then $50 \mathrm{cycles}$ at $95^{\circ} \mathrm{C} / 15 \mathrm{sec}, 60^{\circ} \mathrm{C} / 1 \mathrm{~min}$. To calculate the percentage of enrichment at miR200b locus, for each particular mark a fold change of expression relative to IgG is first calculated. Then this fold change is converted into nanograms of DNA based on the input DNA calibration curve set up in each qPCR. Final data are represented as percentages of miR200b loci enriched by various anti-histone antibodies from $30 \mu \mathrm{g}$ of input DNA for each immunoprecipitation. The efficiency of ChIP depends on the efficiency of the antibody (recognition of the epitopes). All antibodies used in this study were polyclonal, however the number of available epitopes exposed on the surface of each histone is not known. Consistently, the $\mathrm{H} 3$ antibody shows a poorer performance than most antibodies against $\mathrm{H} 3$ modifications (others have published similar observations, regardless of the anti-H3 antibody used). It only makes sense to compare relative levels of enrichment with individual antibodies between biological samples.

\section{Results and discussion}

A Principle of ChIP in droplets assay 
The proof of concept of the ChIP in droplets assay was demonstrated by generating a sequence of $100 \mathrm{~nL}$ confined droplets containing in the first droplet the MB and the chromatin sample, and for the others droplets, reagents needed for all steps of the ChIP procedure. Droplets were used (i) for compartmentalization to prevent cross contaminations, (ii) to reduce sample and reagent consumption and (iii) to increase reaction kinetics. The MB were handled by magnetic tweezers (MT) previously developed by our group. By switching $O N$ the $M T, M B$ in droplets are confined and extracted. The cluster of $M B$ can be resuspended in a new droplet by switching OFF the MT. In that way MB grafted with anti-histone antibodies were used to extract the target chromatin to be analyzed. MB were then transferred from droplets to droplets in order to perform the multi-step ChIP protocol including chromatin binding, washing, elution and purification of DNA. The developed protocol consists of generating two trains of droplets. The first train of droplets was dedicated to chromatin extraction and DNA reverse crosslinking. After cell lysis and chromatin fragmentation, chromatin fragments were specifically captured, based on histone and anti-histone $M B$ interactions, extracted and rinsed through droplets of washing buffers. Then MB were successively resuspended in RNase A and proteinase $\mathrm{K}$ droplets to digest RNA and proteins. DNA was released from the digested proteins by thermal elution and MB were discarded from the proteinase $\mathrm{K}$ droplet. The second train of droplets was generated for DNA purification by transferring ChargeSwitch MB (CSMB) into the DNA / digested proteins droplet (proteinase K droplet). After DNA capture and washing steps, CSMB were resuspended in the elution droplet in order to obtain a pure DNA solution. Finally, gene-histone associations were determined by qPCR amplification. We first targeted histone $\mathrm{H} 3$ and the amount of miR-200b gene was quantified by qPCR in order to investigate and optimize the influence of different parameters on ChIP in droplet sensitivity. Then we studied the efficiency of this new platform to analyze histone modifications (methylation, acetylation) involved in gene activation and

(A)

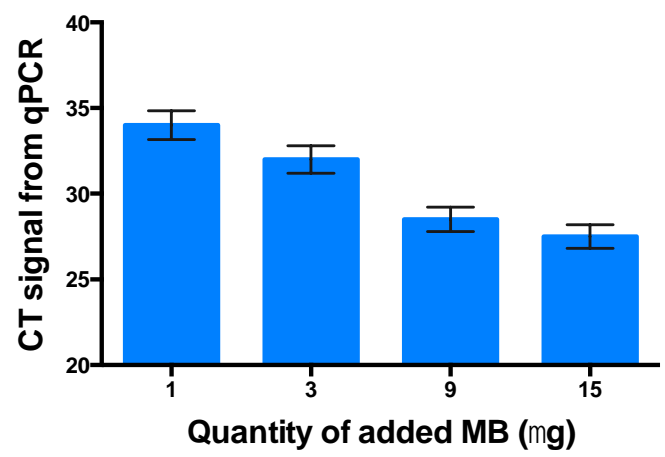

(B)

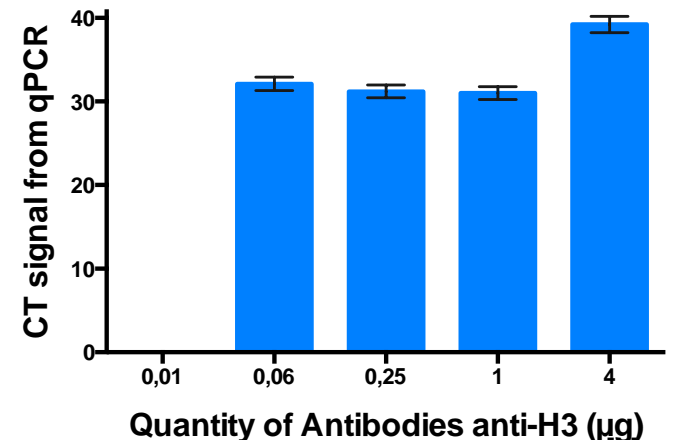

Fig.3. A) Influence of the quantity of added magnetic beads (MB) on the CT signal from the qPCR for the enrichment of H3 at miR-200b promoter. The input of total chromatin and anti-H3 antibody quantity was set to 12 and $1 \mu \mathrm{g}$, respectively. B) Influence of the quantity of anti-H3 antibodies on the CT signal from the qPCR. The input of total chromatin and MB quantity was set to 12 and $15 \mu \mathrm{g}$, respectively. RSD $=2.5 \%(\mathrm{~N}=3$ )

repression of transcription processes.

\section{B Influence of the quantity of added magnetic beads on ChIP assay performances}

Anti-H3 MB were used as a solid support for the target chromatin capture and extraction. Different quantities of MB ranging from 1 to $15 \mu \mathrm{g}$ were added and fully extracted after chromatin capture while keeping all others parameters constant. Quantities of chromatin and antibodies were set at 12 and $1 \mu \mathrm{g}$, respectively. As seen in Fig.3.a, the CT (cycle threshold) obtained by qPCR decreases when the quantity of added MB increases, indicating an increased sensitivity. The MB extraction is governed by the magnetic force generated between the MT compared to the interfacial force as previously described ${ }^{20}$. Here the maximum quantity of captured anti-H3 MB is $15 \mu \mathrm{g}$. Beyond this value, the produced MB cluster exceed the magnetic confinement volume offered by the MT geometry. Higher current intensity would be required to confine greater amounts of MB quantity, however this approach would also necessitate bulky equipment to maintain the same magnetic force and gradient. In order to demonstrate the specificity of the immunoprecipitation, non-specific IgG antibodies were used as negative control. Using added $\mathrm{MB}$ in the 1-15 $\mu \mathrm{g}$ range, the $\mathrm{CT}$ values remained in the range of background signal, thus demonstrating that the specificity of the procedure was not affected by MB quantity. For subsequent experiments, we fixed the quantity of MB at $15 \mu \mathrm{g}$.

\section{Influence of anti-histone antibodies quantity on ChIP in droplet assay performances}

The sensitivity of the developed procedure is also governed by the quantity of anti-H3 antibody used to specifically extract the target chromatin. In order to highlight the influence of anti $\mathrm{H} 3$ quantity on assay sensitivity, the quantity of MB and chromatin were set to $15 \mu \mathrm{g}\left(1.5 \times 10^{6} \mathrm{MB}\right)$ and $12 \mu \mathrm{g}$, respectively, while anti-H3 antibody quantity varied from 0.01 to $4 \mu \mathrm{g}$. As observed in 


\begin{tabular}{|c|c|c|c|c|c|c|c|c|}
\hline & $\begin{array}{c}\text { MB } \\
\text { quantity }\end{array}$ & $\begin{array}{c}\text { Antibody } \\
\text { quantity }\end{array}$ & $\begin{array}{c}\text { Chromatin } \\
\text { quantity }\end{array}$ & $\begin{array}{c}\text { Chromatin } \\
\text { immuno- } \\
\text { precipitation }\end{array}$ & $\begin{array}{c}\text { DNA } \\
\text { elution }\end{array}$ & $\begin{array}{c}\text { DNA } \\
\text { purification }\end{array}$ & qPCR & $\begin{array}{c}\text { Total } \\
\text { Time }\end{array}$ \\
\hline Droplet ChIP & $15 \mu \mathrm{g}$ & $0,06 \mu \mathrm{g}$ & $0,1 \mu \mathrm{g}$ & $4 \mathrm{~h}$ & $20 \mathrm{~min}$ & $20 \mathrm{~min}$ & $2 \mathrm{~h}$ & $7 \mathrm{~h}$ \\
\hline $\begin{array}{c}\text { Conventional } \\
\text { ChIP }\end{array}$ & $300-900 \mu \mathrm{g}$ & $1-5 \mu \mathrm{g}$ & $10-30 \mu \mathrm{g}$ & $24 \mathrm{~h}$ & $1 \mathrm{~h}$ & $24 \mathrm{~h} *$ & $2 \mathrm{~h}$ & $51 \mathrm{~h}$ \\
\hline
\end{tabular}

* Due to the lengthy protocol some steps, such as DNA decrosslinking and/or DNA precipitation, are usually performed over night.

Tab.1. Comparison of the droplet and conventional ChIP analytical performances.

Fig.3.B there is no signal when the anti-H3 quantity is $0.01 \mu \mathrm{g}$. The absence of signal may result from the synergetic effect of the following phenomenon: first the quantity of antibody is too low to efficiently interact with $\mathrm{H} 3$ histone, second the $\mathrm{MB}$ specific surface is so high that antibodies are instantly captured on the MB thus becoming less available to efficiently interact with $\mathrm{H} 3$ compared to free anti $\mathrm{H} 3$ antibodies. The effect of these phenomenon decreases when antibody concentration increases. In addition, a loss of antibodies and chromatin may occur after molecules adsorption on tube walls or droplet internal surface. In both cases the surfaces are treated (by the manufacturer for the tubes and using surfactant in our droplet platform) to avoid nonspecific adsorption. For anti-H3 quantities ranging from 0.06 to $1 \mu \mathrm{g}$ the CT value obtained by qPCR was constant: in this range of values the quantity of anti-H3 is high enough to efficiently capture the specific chromatin while the surface of the MB is not saturated. At a quantity of $4 \mu \mathrm{g}$ we observed an increase of the CT value, indicating reduced sensitivity. In these conditions, the quantity of anti- $\mathrm{H} 3$ is in excess compared to chromatin, therefore introducing competition between free anti- $\mathrm{H} 3$ and anti$\mathrm{H} 3 /$ chromatin complex for the surface of the $\mathrm{MB}$. This condition leads to steric hindrance at the surface of the MB thus explaining the decrease of assay sensitivity.

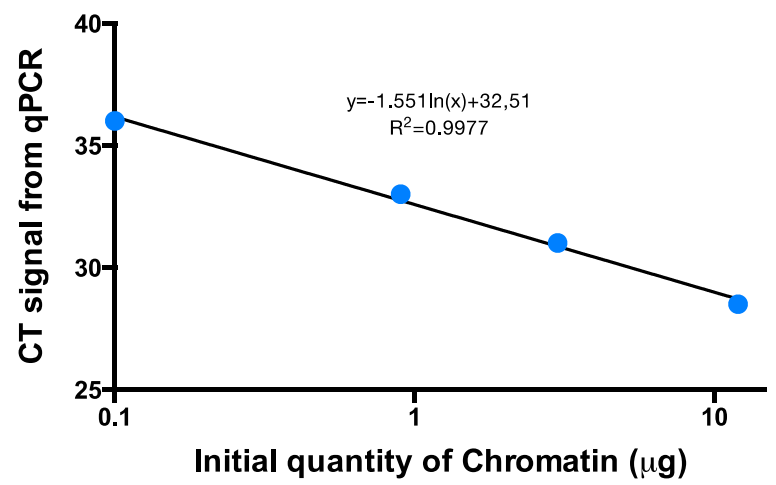

Fig.4. Influence of the initial quantity of chromatin on the CT signal from the qPCR. The anti-H3 antibody and MB quantity was set to 0.25 and $15 \mu \mathrm{g}$, respectively. $\mathrm{RSD}=2.5 \%(\mathrm{~N}=3)$.

\section{Influence of initial chromatin quantity on ChIP in droplet assay performances}

One of the main limitations concerning ChIP performances is the requisite use of large numbers of cells, thus prohibiting its application to analyses of rare cells. We found that the lowest quantity of input chromatin required to obtain a significant signal in our system was about $0.1 \mu \mathrm{g}$ (Fig.4), which corresponds to the amount of chromatin extracted from about 10,000 cells considering that a diploid mammalian cell contains approximately $10 \mathrm{pg}$ of DNA. This new method therefore permits the reduction of the number of starting cells by two orders of magnitude, compared to conventional ChIP approaches. The overall performances of the ChIP in droplet platform are summarized in the table 1, highlighting the time and reagents consumption for both conventional and droplet approaches. The droplet approach enables a 7-fold reduction in analytical time, as well as a 100-, 20-, and 16-fold reduction in chromatin, MB and antibody consumption, respectively.

\section{E Study of miR-200b expression for HT1080 in droplets microfludic versus conventional method}

Based on the results of $\mathrm{H3}$ analysis, we investigated the enrichment of histone active/repressive marks at the miR-200b promoter. This gene belongs to the micro RNA family 200 of non-coding RNAs involved in regulation of cancer progression. miR$200 \mathrm{~b}$ is deregulated in different cancers ${ }^{24}$ and its aberrant down-expression is also known to enhance tumor invasion ${ }^{25-27}$. 
Furthermore, a prognostic value of miR-200b in different cancers has been shown ${ }^{28-30}$. Histone modifications, such as methylation or acetylation have a direct influence on gene activation or repression. In this context, we analyzed two active marks (H3K4me3, H3K9ac) and two repressive marks (H3K9me3 and H3K27me3) at the miR-200b promoter in a cancer cell line H1080, which has been previously shown to express low to undetectable levels of miR-200b ${ }^{31}$.

Using the droplet technique, we showed a strong enrichment of repressive marks H3K9me3 and H3K27me3 at the miR-200b promoter (Fig.5), consistent with the published repressed status of the miR-200b promoter in this cancer cell line ${ }^{31}$. Furthermore, the H3K9ac active mark was poorly represented at the locus. Unexpectedly, we detected a fair enrichment of an active mark $\mathrm{H} 3 \mathrm{~K} 4 \mathrm{me} 3$, suggesting the bivalent nature of the miR-200b promoter, showing both repressive and active marks. Since the repressive marks are more prevalent, this gene is repressed in $\mathrm{H} 1080$.

To confirm that results obtained using the droplet technique are comparable to those obtained by conventional ChIP methods, we performed a manual ChIP using the same chromatin preparation and antibody lots, but at lower concentrations than the one recommended for the manual ChIP. Very similar results were obtained by both techniques (Fig.5), validating the use of the proposed droplet approach to study the histone modifications at a particular locus of interest. In additional to significantly reducing the amount of the starting reagents needed, the droplet approach is more efficient since the percentage of captured DNA is higher for all enriched marks tested. The confinement of analytical steps to droplets minimizes DNA loss, which may occur at various steps such as immunoprecipitation, washing, DNA elution and purification steps. When we attempted a conventional ChIP method with the same concentrations of reagents as used in droplets, the ChIP was 10 times less efficient, thus attesting to the benefits of the droplet technique (Fig.5).

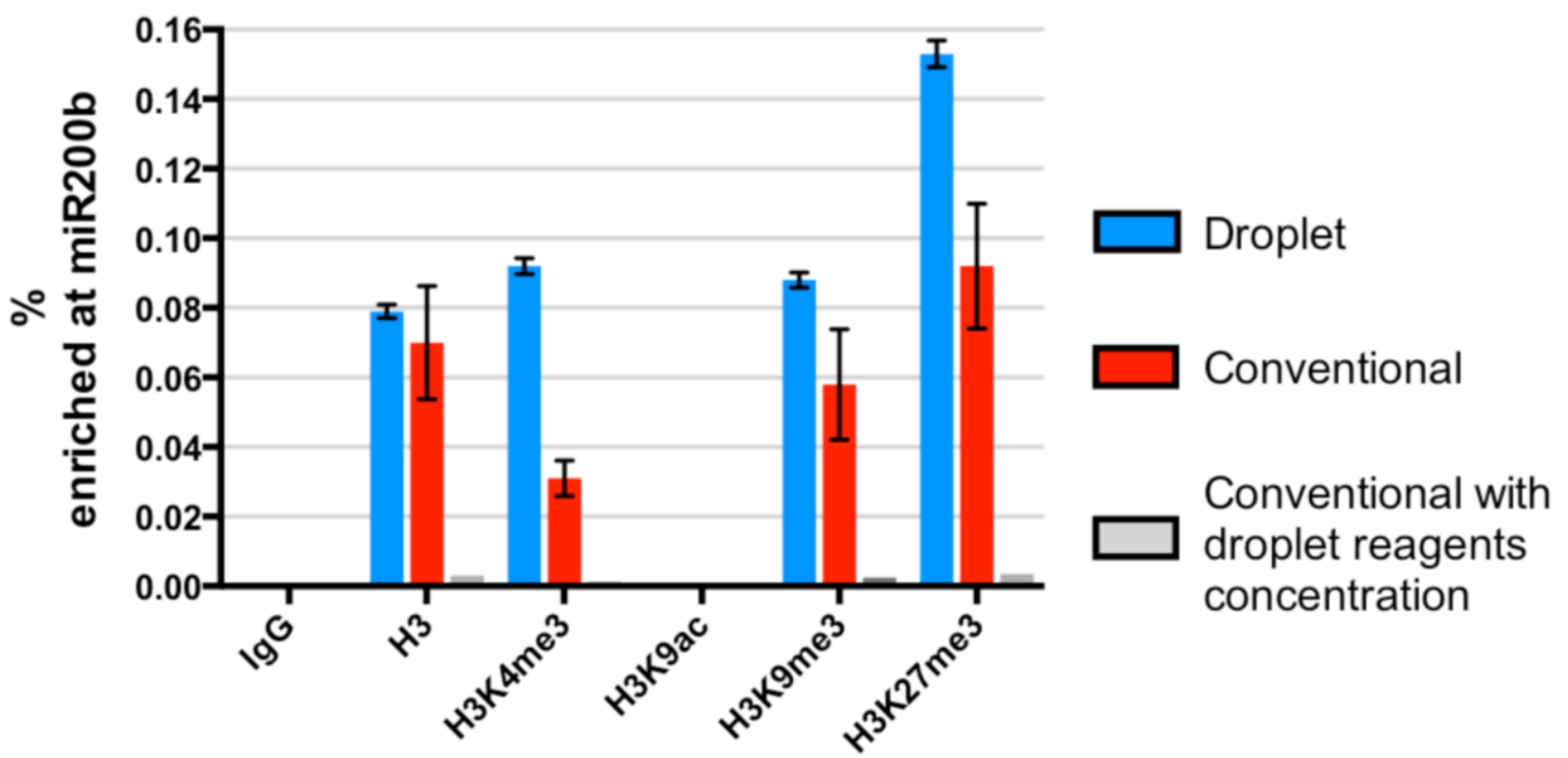

Fig.5. Percentage of enrichment at miR200b for negative control (IgG), positive control (H3), active marks (H3K4me3, H3K9ac) and repressive marks (H3K9me3, H3K27me3) using droplet, conventional techniques or conventional technique with droplet reagents concentration (Droplet experiments average $\mathrm{RSD}=2.5 \%$, Conventional experiments average $\mathrm{RSD}=20,7 \%$ ).

\section{Conclusions}

We have demonstrated a new ChIP approach combining droplets, MB and magnetic tweezers. This platform takes advantage of $\mathrm{MB}$ used as a capture support to achieve a sequential and multi-step protocol, combined with droplets to compartmentalize individual reactions at a nanoliter scale. The integrated steps of chromatin extraction, DNA elution and purification were completed in shorter analysis time with reduced sample consumption while offering greater sensitivity than a conventional ChIP assay. We demonstrated that the ChIP in-droplet was an efficient technique to evaluate histone modifications at a locus of interest. We described the bivalent nature of the miR-200b locus with a prevalence of repressive marks, suggesting a low or negligible expression of miR-200b in HT1080, as described previously ${ }^{31}$. Finally, we validated the performances of the developed ChIP in-droplet technique by obtaining a similar profile of histone modifications using conventional ChIP methods. This new platform is therefore an efficient tool for ChIP analyses with increased sensitivity, improved processing time and greater cost effectiveness. In addition, since this is a low-cost approach, the platform offers the possibility to incorporate multiple tubes containing trains of droplet sequences, thus opening the way to develop easy multiplex assays. We envision also to combine our 
lab-on-tube platform with previously described micro-devices dedicated to chromatin preparation in order to create a complete pipeline for the automated analysis of DNA-protein associations, starting from live cells.

\section{Acknowledgements}

This work was supported by European research Council Advanced Grant N:321107 “CellO", by Investissement d'avenir ANR projects "Digidiag" and IPGG, and by Nadine and Diatools European Projects (FP7). Work in the Telomere and cancer laboratory is supported by a grant from INCa (CINEPIMIR). We thank Karina Jouravleva for communicating results prior publication. The authors also thank C. M. Gillis for proofreading this article.

\section{Notes and references}

1. A. Barski, S. Cuddapah, K. R. Cui, T. Y. Roh, D. E. Schones, Z. B. Wang, G. Wei, I. Chepelev and K. J. Zhao, Cell, 2007, 129, 823837.

2. T. Zhang, S. Cooper and N. Brockdorff, EMBO Rep, 2015, 16, 1467-1481.

3. P. A. Jones and S. B. Baylin, Nature Reviews Genetics, 2002, 3, 415-428.

4. G. Sadri-Vakili and J. H. J. Cha, Nature Clinical Practice Neurology, 2006, 2, 330-338.

5. B. D. Strahl and C. D. Allis, Nature, 2000, 403, 41-45.

6. T. Kouzarides, Cell, 2007, 128, 693-705.

7. P. Collas, Molecular Biotechnology, 2010, 45, 87-100.

8. V. W. Zhou, A. Goren and B. E. Bernstein, Nature Reviews Genetics, 2011, 12, 7-18.

9. L. G. Acevedo, A. L. Iniguez, H. L. Holster, X. Zhang, R. Green and P. J. Farnham, Biotechniques, 2007, 43, $791-797$.

10. J. A. Dahl and P. Collas, Nature Protocols, 2008, 3, 1032-1045.

11. D. Lara-Astiaso, A. Weiner, E. Lorenzo-Vivas, I. Zaretsky, D. A. Jaitin, E. David, H. Keren-Shaul, A. Mildner, D. Winter, S. Jung, N. Friedman and I. Amit, Science, 2014, 345, 943-949.

12. J. D. Nelson, O. Denisenko and K. Bomsztyk, Nature Protocols, 2006, 1, 179-185.

13. S. Flanagin, J. D. Nelson, D. G. Castner, O. Denisenko and K. Bomsztyk, Nucleic Acids Research, 2008, 36, 9.

14. B. Teste, F. Malloggi, J.-M. Siaugue, A. Varenne, F. Kanoufi and S. Descroix, Lab on a Chip, 2011, 11, 4207-4213.

15. G. Mottet, K. Perez-Toralla, E. Tulukcuoglu, F.-C. Bidard, J.-Y. Pierga, I. Draskovic, A. Londono-Vallejo, S. Descroix, L. Malaquin and J. L. Viovy, Biomicrofluidics, 2014, 8.

16. A. R. Wu, T. L. A. Kawahara, N. A. Rapicavoli, J. van Riggelen, E. H. Shroff, L. Xu, D. W. Felsher, H. Y. Chang and S. R. Quake, Lab on a Chip, 2012, 12, 2190-2198.

17. T. Geng, N. Bao, M. D. Litt, T. G. Glaros, L. Li and C. Lu, Lab on a Chip, 2011, 11, 2842-2848.

18. Z. N. Cao, C. Y. Chen, B. He, K. Tan and C. Lu, Nature Methods, 2015, 12, 959-962.

19. Z. Cao and C. Lu, Anal Chem, 2016, 88, 1965-1972.

20. A. Ali-Cherif, S. Begolo, S. Descroix, J.-L. Viovy and L. Malaquin, Angewandte Chemie-International Edition, 2012, 51, 1076510769.

21. B. Teste, N. Jamond, D. Ferraro, J.-L. Viovy and L. Malaquin, Microfluidics and Nanofluidics, 2015, 19, 141-153.

22. B. Teste, A. Ali-Cherif, J. L. Viovy and L. Malaquin, Lab Chip, 2013, 13, 2344-2349.

23. D. Ferraro, J. Champ, B. Teste, M. Serra, L. Malaquin, J. L. Viovy, P. de Cremoux and S. Descroix, Sci Rep, $2016,6,25540$.

24. A. Li, N. Omura, S.-M. Hong, A. Vincent, K. Walter, M. Griffith, M. Borges and M. Goggins, Cancer Research, 2010, 70, 52265237.

25. J. Kurashige, K. Mima, G. Sawada, Y. Takahashi, H. Eguchi, K. Sugimachi, M. Mori, K. Yanagihara, M. Yashiro, K. Hirakawa, H. Baba and K. Mimori, Carcinogenesis, 2015, 36, 133-141.

26. J. Kurashige, H. Kamohara, M. Watanabe, Y. Hiyoshi, M. Iwatsuki, Y. Tanaka, K. Kinoshita, S. Saito, Y. Baba and H. Baba, Annals of Surgical Oncology, 2012, 19, S656-S664.

27. C. P. Bracken, X. C. Li, J. A. Wright, D. M. Lawrence, K. A. Pillman, M. Salmanidis, M. A. Anderson, B. K. Dredge, P. A. Gregory, A. Tsykin, C. Neilsen, D. W. Thomson, A. G. Bert, J. M. Leerberg, A. S. Yap, K. B. Jensen, Y. Khew-Goodall and G. J. Goodall, Embo Journal, 2014, 33, 2040-2056.

28. Y. Yao, J. Hu, Z. Shen, R. Yao, S. Liu, Y. Li, H. Cong, X. Wang, W. Qiu and L. Yue, Journal of Cellular and Molecular Medicine, 2015, 19, 760-769.

29. C. U. Koehler, O. Bryk, S. Meier, K. Lang, P. Rozynek, T. Bruening and H. U. Kaefferlein, Biochemical and Biophysical Research Communications, 2013, 438, 48-53.

30. D. D. Taylor and C. Gercel-Taylor, Gynecologic Oncology, 2008, 110, 13-21.

31. A. Marimuthu, T.-C. Huang, L. D. N. Selvan, S. Renuse, R. S. Nirujogi, P. Kumar, S. M. Pinto, S. Rajagopalan, A. Pandey, H. C. Harsha and A. Chatterjee, EuPA Open Proteomics, 2014, 4, 10-17. 
$10 \mid$ J. Name., 2012, 00, 1-3 